\title{
Preliminary landslide mapping in Greenland
}

\author{
Kristian Svennevig*1
}

RESEARCH ARTICLE | OPEN ACCESS

GEUS Bulletin Vol 43 | e2019430207 | Published online: 17 June 2019

https://doi.org/10.34194/GEUSB-201943-02-07

The landslide of 17 June 2017 in Karrat Fjord, central West Greenland, highlighted the need for a better understanding of landslides and landslide-generated tsunamis in Greenland and motivated a landslide screening project in 2018, led by the Geological Survey of Denmark and Greenland (GEUS; see also Svennevig et al. this volume). A central part of this project was to conduct a preliminary mapping of Quaternary and historical landslides in Greenland - the first effort of its kind. The main objective was to establish a landslide inventory database that can be used to identify areas prone to landslides and serve as a tool for gaining a better understanding of where, when and why catastrophic landslides take place in Greenland.

This paper describes the workflow used to produce the preliminary landslide inventory of Greenland and discusses some of the initial results. To date (June 2019), I have mapped 564 landslides with the vast majority situated in the Nuussuaq Basin between Sigguup Nunaa (Svartenhuk Halvø), and Qeqertarsuaq (Disko) in West Greenland (Fig. 1). The inventory mapping is mainly based on observations and analyses of remotely sensed imagery and pre-existing geological maps. The mapping coverage was not systematic for all of Greenland, but focused on postglacial, potentially tsunamigenic landslides in inhabited coastal regions, i.e. on relatively large landslides on coastal slopes, mainly in West Greenland and small areas of East Greenland. However, smaller and inland landslides were included when they were encountered. Similarly, the less inhabited parts of Greenland were provisionally screened, but call for more thorough, systematic mapping in the future.

\section{Existing Records}

Records of landslides in Greenland are sparse and were collected ad hoc. Only three large landslides are known historically, one in 1952, one in 2000 and another in 2017 (Fig. 1). A previously unnamed landslide on the south coast of
Nuussuaq in 1952 generated a tsunami that caused one fatality, and was observed in the mining town of Qullissat on northern Qeqertarsuaq (Dahl-Jensen et al. 2004). The circumstances of the landslide are poorly known as it has not been examined in detail. This landslide is herein named the ' 1952 Niiortuut landslide' after a nearby mountain peak. The 2000 Paatuut landslide (Fig. 1) caused a tsunami with near-field wave heights in the order of $50 \mathrm{~m}$ that ravaged the then abandoned town of Qullissat. It is the only landslide-tsunami event in Greenland to be described in detail (Pedersen et al. 2002; Dahl-Jensen et al. 2004). The 2017 landslide in Karrat Fjord was described at a reconnaissance level of detail by Bessette-Kirton et al. (2017) and Gauthier et al. (2018), and subsequent minor landslide activity at the site was described by Svennevig et al. (2019). The landslide triggered a tsunami that caused four fatalities in the nearby village of Nuugaatsiaq (Paris et al. 2019). Additionally, Kelly (1980) described a pre-historic rock avalanche deposit 25 $\mathrm{km}$ north-east of Sisimiut at Aqqutikitsoq mountain, and speculated that it occurred in the 16th or 17th century based on, among other things, the deposits relation to a local Little Ice Age moraine. This landslide is herein referred to as the 'Aqqutikitsoq rock avalanche'.

Prehistoric landslide deposits were mapped in sedimentary basins and extrusive terrains on a number of published 1:100 000 scale geological maps of Greenland (e.g. Fig. 2A). These are mainly the map sheets covering the area from Sigguup Nunaa to Qeqertarsuaq in West Greenland $\left(72^{\circ} 20^{\prime} \mathrm{N}\right.$ to $69^{\circ} 10^{\prime} \mathrm{N}$ ), and Jameson Land and the Scoresby Sund area in East Greenland $\left(72^{\circ} 00^{\prime} \mathrm{N}\right.$ to $\left.70^{\circ} 00^{\prime} \mathrm{N}\right)$. No landslide deposits were mapped on Precambrian 'basement' lithologies. Some of the landslide deposits on the 1:100 000 scale maps in West Greenland were included on the seamless 1:500 000 scale geological map of Greenland (Pedersen et al. 2013).

On five 1:500 000 scale Quaternary geological maps in a now discontinued map series compiled by A. Weidick and others (see Holst et al. 2013), block/rock glaciers, mudflows, 


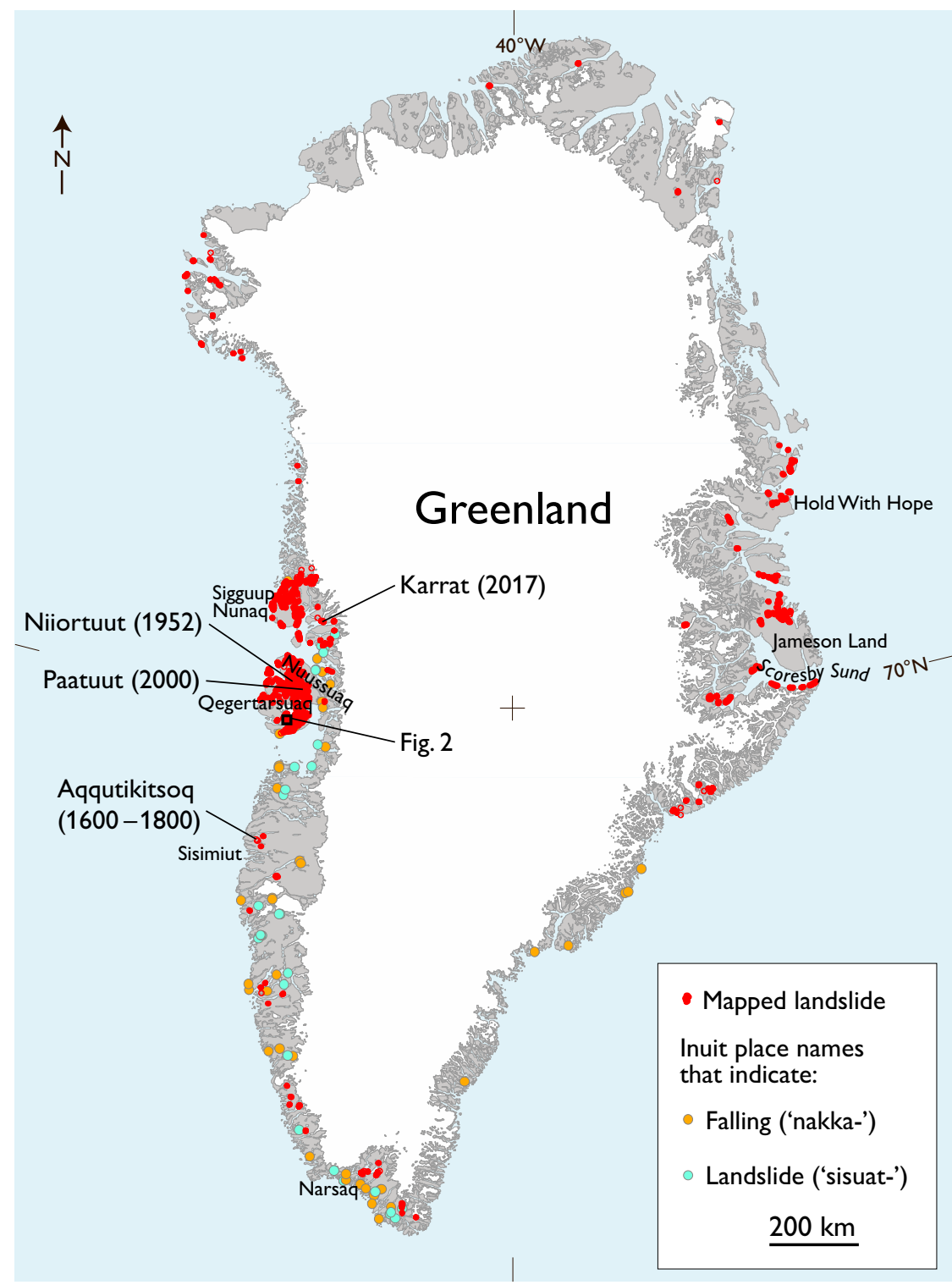

Fig 1. Overview map of Greenland showing the 564 mapped landslides and Inuit place names indicative of landslides, along with the four previously described landslides and their years of occurrence. Place names mentioned in the text and the position of Fig. 2 are also shown. The outline of single landslides are exaggerated for visibility on the small map scale. The concentration of landslides in the Nuussuaq Basin stretching from Sigguup Nunaa (Svartenhuk Halvø) to Qeqertarsuaq (Disko) in central West Greenland, stands out.

and landslides were described, but inconsistently mapped. For example, landslides were only mapped in Jameson Land, where they are in general agreement with some of the landslides mapped on the 1:100 000 scale maps. Some of the block and rock glaciers mapped by Weidick and others are actually landslide deposits, as is the case with the Aqqutikitsoq rock avalanche previously mentioned.

Three minor prehistoric landslides were recorded along the coast north of Hold With Hope on a 1:250 000 scale geological map of East Greenland (Koch \& Haller 1971). Four relatively small prehistoric landslides around Narsaq, South Greenland were mapped by Funder (1979).

\section{Greenlandic Inuit place names}

An unexpected data source for landslide activity indicators was the Greenlandic place name database obtained from Oqaasileriffik - The Language Secretariat of Greenland. Inuit place names are particularly descriptive (Kleivan 1986; Kruse 2012) and some of them are indicative of landslide or rock-fall activity. This includes the linguistic roots 'nakka-' (falling (-down)) and 'sisuat-' (landslide), which are directly indicative of activity (Fig. 1). Other words such as 'pingu-' (earth mound), 'maniillat-' (uneven/bumpy) and 'qerrut-' (rock pile) are indicative of geomorphological features that could be formed during landslide activity and warrant further investigation. Extracting landslide data from place names is a work in progress, and several factors need to be addressed, including inconsistency issues related to local dialects and verifying that place names identified in the data- 
base actually match landslides in the field. Until this work can be done, Inuit place names that might indicate landslide activity are shown in Fig. 1 but are not included in the inventory.

\section{Current landslide mapping}

The principal data sources used for mapping were a $2 \mathrm{~m}$ resolution Digital Elevation Model (DEM) and the satellite images available in Google Earth. In areas where the resolution of the Google Earth images is insufficient, Sentinel-2 satellite images were used (e.g. Fig. 2B). In areas of particular interest such as the Karrat area and the Nuussuaq peninsula, the Sentinel-2 images were supplemented with high-resolution oblique and nadir aerial images from the GEUS archive. Postglacial landslides, the focus of this mapping exercise, are often clearly visible in a hillshade image created from a highresolution DEM (e.g. Fig. 2C). Until recently, a high-resolution DEM did not exist for all of Greenland, but with the release of the publicly available ArcticDEM, Greenland is now covered at a $2 \mathrm{~m}$ resolution (Porter et al. 2018). The DEM is mostly based on WorldView satellite stereo images with a maximum resolution of $0.40 \mathrm{~m}$. Several time series of DEMs, some extending back to 2009, are available for the same locations, which makes it possible to follow the evolution of active landslides. In the sedimentary basins where rotational type landslides (sensu Hungr et al. 2014) are most common, landslides are recognised either by the shape of their arcu-

Fig. 2. Three spatial datasets of the same area in Daugaard-Jensen Dal, central Qeqertarsuaq (Disko), West Greenland. See Fig. 1 for location. Mapped landslides are outlined by red dashed lines. A: Extract from the 1:100 000-scale geological map (Pedersen et al. 2001). Landslide deposits (1s) are greyish purple, basalt members of the Maligât Formation are

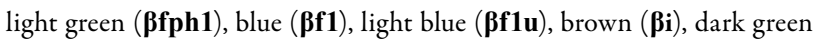
$(\boldsymbol{\beta f 2})$ and pink ( $\boldsymbol{\beta f 3})$. At the base of the central landslide deposit, Paleocene mudstones (Pmu) of the Atanikerluk Formation are exposed. These may have provided the failure surface for the central landslide as is also suggested for the 2000 Paatuut landslide $80 \mathrm{~km}$ to the north (Pedersen et al. 2002; Dahl-Jensen et al. 2004). B: Sentinel-2A satellite image from 8 August 2018. C: Hillshade from ArcticDEM (Porter et al. 2018) of the area illuminated from the north-east. What appears to be a single landslide deposit in the geological map (A) is actually, on closer inspection of the Arctic DEM (C), two landslides: A large slide on the south-facing slope with well-defined rotated blocks, here called the Daugaard-Jensen Dal landslide $(\mathbf{X})$, and a smaller slide to the east on the north-facing slope (Y). West of the Daugaard-Jensen Dal landslide are two smaller arcuate head scarps with no landslide deposits; such deposits may be buried under the deposits of the braided river. To the east of this feature, the river has incised the toe of the Daugaard-Jensen Dal landslide by up to $80 \mathrm{~m}$. In the Kuannersuit Kuussuat valley to the north-west, several large landslides were also mapped.
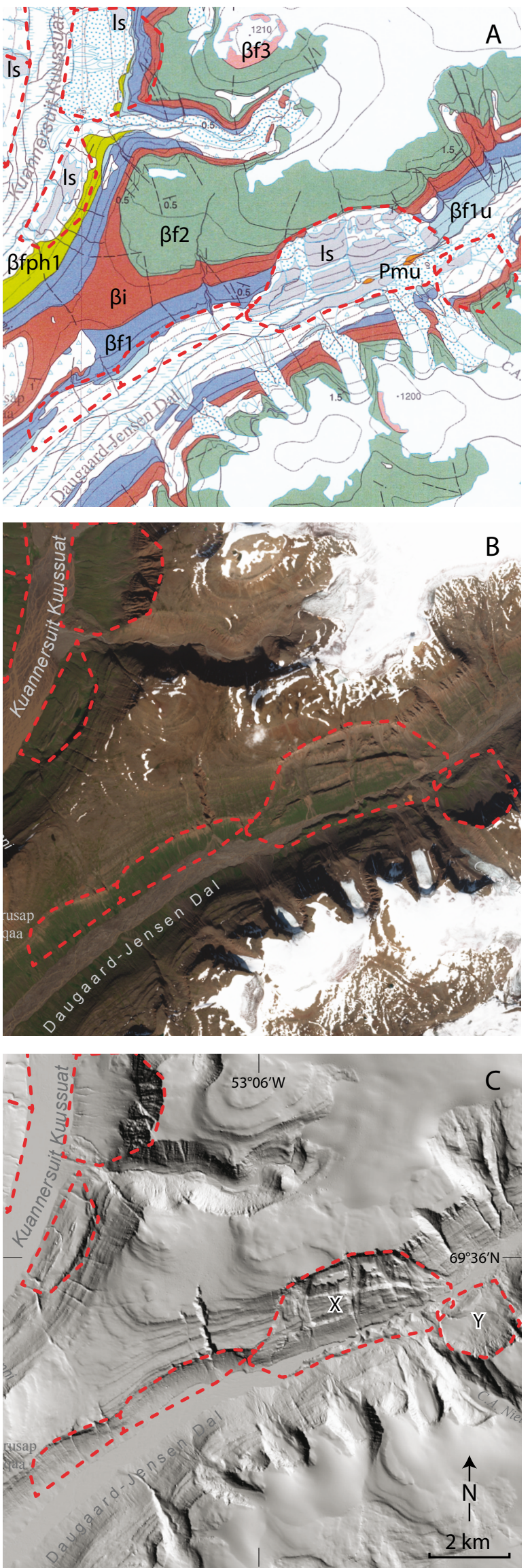
ate headscarp on otherwise smooth glacial valley sides, or by rotated blocks on the slope, which form valley-parallel ridges and grabens (Fig. 2C). In general, landslide areas have a rough/hummocky morphology compared to surrounding, unfailed areas (e.g. McKean \& Roering 2004), and frequently have immature hydrologic drainage patterns containing many small drainless depressions. In areas underlain by crystalline rocks, landslides were not as easily recognised because headscarps were often irregular, controlled by local development of foliation and fractures. Where landslide deposits were present, debris cones (molards; Milana 2016; Morino et al. 2019) or large boulder fields were regularly observed (e.g. in the Aqqutikitsoq rock avalanche deposit). Elsewhere, scarps were often the only visible sign of landslide, since the primary targets for this mapping were coastal sites where landslide deposits were located below sea level. This problem emphasises the need for detailed bathymetry in future studies. For this preliminary mapping project, submarine areas were generally not examined because of the largely poor bathymetrical data coverage. In a few locations, the bathymetrical compilation Bedmachine $\mathrm{v} 3$ was used (Morlighem et al. 2017) to identify submarine landslide deposits.

Once identified, landslides were mapped in ArcGIS as polygons with a limited number of vertices reflecting the relatively small map scale required to cover all of Greenland. Each polygon represents the slide perimeter from the headscarp to the toe, defined by the most distal slide deposit, if present. In some cases, only the headscarp and slide scar were mapped (e.g. Fig. 2) and in a few other cases, only the landslide deposit was mapped.

In the GIS software, the attribute table contains data for each polygon of the mapped landslides, including a suggested or given name, references, year, month, geographical area, slope aspect, slide height $(\mathrm{H})$, slide length $(\mathrm{L}), \mathrm{H} / \mathrm{L}$ ratio, local presence of bedrock dipslope (seaward dipping strata/ foliation), coincidence with landslide deposits shown in the 1:100 000 scale geological maps and generalised bedrock composition.

\section{Preliminary results and outlook}

So far, I have mapped 564 landslides throughout Greenland. The Nuussuaq Basin covers roughly $4.7 \%$ of the ice-free area of Greenland, however, this area holds 376 of the 564 mapped landslides (67\%). This confirms the previous identification of this area as a landslide 'hot spot' in Greenland (Pedersen et al. 2002; Dahl-Jensen et al. 2004). The geological region of Karrat, within which the 2017 landslide took place, covers $3.8 \%$ of the ice free area of Greenland. Here, 18 landslides are mapped, comprising 3.3\% of the total, and thus this region as a whole is not considered a landslide 'hot spot'.

As previously mentioned, the present mapping is preliminary and focused on the populated parts of Greenland. However, all of Greenland has been screened in varying detail. To produce a more accurate picture of landslide distribution throughout Greenland, a more detailed and systematic mapping effort of the less populated parts of Greenland is needed. Furthermore, the inclusion of all available bathymetric data to map landslide deposits in the fjords would greatly add to the quality of the dataset. This is especially the case for the Precambrian basement-dominated parts of West and South-East Greenland, where slide scarps are often difficult to identify as they are controlled by local foliation and fracture patterns. Classification of the landslides, following commonly used classifications schemes where possible (Highland \& Bobrowsky 2008; Hungr et al. 2014), is pending, and would further add to the value of the landslide inventory. Additional remote sensing and fieldwork at selected sites to validate the observations would further increase the quality of the dataset. But the cost of Arctic field work is a limiting factor and hence careful selection of sites is essential.

Another valuable add on would be sampling for absolute dates at key localities to constrain the frequencies of landslide events. Available dating methods include cosmogenic nuclei analysis of headscarps and boulders, and C14-dating of sediments associated with marine landslide deposits or the small lakes formed by landslide activity (Pánek 2015). A less direct method would be to examine near coastal lakes for tsunami deposits, and then date these deposits. Relative age determination from remote sensing data sets using the surface roughness from high resolution DEM (McCalpin 1984) or analysis of lichen cover from hyperspectral data as a proxy might be helpful in smaller regions and could be supported by a small number of absolutely dated landslides.

The landslide database will be published in full with a digital appendix containing mapped polygons and attribute table when it covers all of Greenland at a satisfactory scale. Spatial statistical analysis on the database could be carried out in combination with available topographical, geological and climate data to improve the understanding of landslides in Greenland, and in the Arctic in general. This would help to identify where, when and why landslides happen in the Arctic, and give some indication of the future hazards and risks from landslides in Greenland. 


\section{Acknowledgments}

Thanks to Andrée Blais-Stevens and Jeffrey A. Coe for constructive reviews, to Lotte Melchior Larsen for helpful comments on the manuscript and Majken Djurhuus Poulsen for reviewing the Inuit place name paragraph.

\section{References}

Bessette-Kirton, E., Allstadt, K., Pursley, J. \& Godt, J. 2017: Preliminary Analysis of Satellite Imagery and Seismic Observations of the Nuugaatsiaq Landslide and Tsunami, Greenland. https://www.usgs. gov/natural-hazards/landslide-hazards/science/preliminary-analysissatellite-imagery-and-seismic?qt-science_center_objects $=0 \# \mathrm{qt}$-science_center_objects.

Dahl-Jensen, T. et al. 2004: Landslide and tsunami 21 November 2000 in Paatuut, West Greenland. Natural Hazards 31, 277-287. http://dx.doi. org/10.1023/b:nhaz.0000020264.70048.95

Funder, S. 1979: The Quaternary geology of the Narssaq area, South Greenland, Grønlands Geologiske Undersøgelse Rapport 86, Copenhagen: Geological Survey of Greenland.

Gauthier, D., Anderson, S.A., Fritz, H.M. \& Giachetti, T. 2018: Karrat Fjord (Greenland) tsunamigenic landslide of 17 June 2017: initial 3D observations. Landslides 15, 327-332. http://dx.doi.org/10.1007/ s10346-017-0926-4

Highland, L.M. \& Bobrowsky, P. 2008: The landslide handbook-A guide to understanding landslides: Reston, Virginia, U.S. Geological Survey Circular 1325, 129 p.

Holst, J., Glendal, E.W. \& Dawes, P.R. 2013: Catalogue of Survey publications on Greenland. Copenhagen: Geological Survey of Denmark and Greenland, 108 pp.

Hungr, O., Leroueil, S. \& Picarelli, L. 2014: The Varnes classification of landslide types, an update. Landslides 11, 167-194. http://dx.doi. org/10.1007/s10346-013-0436-y

Kelly, M. 1980: A prehistoric catastrophic rock avalanche at Holsteinsborg, West Greenland. Geological Society of Denmark Bulletin 28, 73-79.

Kleivan, I. 1986: De grønlandske stednavnes vidnesbyrd om vandringer og forskellige aktiviteter. Vort Sprog - Vor Kultur. Nuuk: Grønlands Landsmuseum, 77-90.

Koch, L. \& Haller, J. 1971: Geological Map of East Greenland $72^{\circ}-76^{\circ} \mathrm{N}$. Lat.(1: 250 000). Meddelelser om Grønland 183, Geological map.

Kruse, L.M. 2012: Stednavne i Grønland. Tidskriftet Grønland 60, 147-156.

McCalpin, J. 1984: Preliminary age classification of landslides for inventory mapping. Proceedings of the Annual Symposium on Engineering Geology and Soil Engineering 21, 99-111.
McKean, J. \& Roering, J. 2004: Objective landslide detection and surface morphology mapping using high-resolution airborne laser altimetry. Geomorphology 57, 331-351. http://dx.doi.org/10.1016/ s0169-555x (03)00164-8

Milana, J.P. 2016: Molards and Their Relation to Landslides Involving Permafrost Failure. Permafrost and Periglacial Processes 27, 271-284. http://dx.doi.org/10.1002/ppp.1878

Morino, C., Conway, S.J., Sæmundsson, P., Kristinn, J., Hillier, J., Butcher, F.E.G., Balme, M.R., Jordan, C., Argles, T., 2019. Molards as an indicator of permafrost degradation and landslide processes. Earth and Planetary Science Letters 516, 136-147. https://doi.org/10.1016/j. epsl.2019.03.040

Morlighem, M. et al. 2017: BedMachine v3: Complete Bed Topography and Ocean Bathymetry Mapping of Greenland From Multibeam Echo Sounding Combined With Mass Conservation. Geophysical Research Letters 44, 11051-11061. http://dx.doi.org/10.1002/2017gl074954

Pánek, T. 2015: Recent progress in landslide dating: A global overview. Progress in Physical Geography 39, 168-198. http://dx.doi. org/10.1177/0309133314550671

Paris, A., Okal, E.A., Guérin, C., Heinrich, P., Schindelé, F. \& Hébert, H. 2019: Numerical Modeling of the June 17, 2017 Landslide and Tsunami Events in Karrat Fjord, West Greenland. Pure and Applied Geophysics, 1-23. https://doi.org/10.1007/s00024-019-02123-5

Pedersen, A.K., Larsen, L.M., Ulff-Møller, F., Pedersen, G.K. \& Dueholm, K.S. 2001: Geolgical map of Greenland, 1:100 000, Pingu 69 V.2 Nord. Copenhagen: Geological Survey of Denmark and Greenland.

Pedersen, M., Weng, W.L., Keulen, N. \& Kokfelt, T.F. 2013: A new seamless digital 1:500 000 scale geological map of Greenland. Geological Survey of Denmark and Greenland Bulletin 28, 65-68.

Pedersen, S.A.S., Larsen, L.M., Dahl-jensen, T., Jepsen, H.F., Krarup, G., Nielsen, T., Pedersen, A.K., Von Platen-Hallermund, F. \& Weng, W.L. 2002: Tsunami-generating rock fall and landslide on the south coast of Nuussuaq, central West Greenland. Geology of Greenland Survey Bulletin 191, 73-83.

Porter, C. et al. 2018: ArcticDEM V2, Harvard Dataverse. https://doi. org/10.7910/DVN/OHHUKH

Svennevig, K., Solgaard, A.M., Dahl-Jensen, T., Boncori, J.P.M., Larsen, T., Salehi, S. \& Voss, P. 2019 (in press): A multidisciplinary approach to landslide monitoring in the Arctic: Case study of the March $2018 \mathrm{ML}$ 1.9 seismic event near the Karrat 2017 landslide. Geological Survey of Denmark and Greenland Bulletin 43, e2019430208.

\section{How to cite}

Svennevig, K. 2019: Preliminary landslide mapping in Greenland. Geological Survey of Denmark and Greenland Bulletin 43, e2019430207. https://doi.org/10.34194/GEUSB-201943-02-07

\footnotetext{
*Corresponding author: Kristian Svennevig|E-mail:ksv@geus.dk

${ }^{1}$ Geological Survey of Denmark and Greenland (GEUS), Øster Voldgade 10, DK-1350, Copenhagen K, Denmark.
} 